\title{
Hubungan Pengetahuan dan Sikap Perilaku Pencegahan Transmisi Covid-19 di Kelurahan Halim Perdana Kusuma
}

\author{
*Diyah Chadaryanti ${ }^{1)}$, Ilah Muhafilah ${ }^{2)}$ \\ ${ }^{1)}$ Program Studi DIII Kebidanan, Fakultas Kesehatan Universitas Mohammad Husni Thamrin \\ ${ }^{2)}$ Program Studi S1 Keperawatan, Fakultas Kesehatan Universitas Mohammad Husni Thamrin
}

Corresponden author: diyahchadaryanti@gmail.com

Received : 16 April $2021 \quad$ Accepted : 23 September $2021 \quad$ Published: 30 September 2021

DOI: https://doi.org/10.37012/jik.v13i2.534

\begin{abstract}
ABSTRAK
Dunia sedang menghadapi wabah Pandemi yang disebabkan virus jenis baru ditetapkan oleh WHO yakni Severe Acute Respiratory Syndrome Coronavirus - 2 (SARS-CoV - 2) sebutan penyakit Coronavirus Disease 2019 (COVID-19). CDC ( Center for Disease Control and Prevention) menyatakan, pasien yang terindikasi COVID-19 menunjukkan gejala ISPA, Ringan sampai berat.Sudah banyak warga dunia dilaporkan dan terkonfirmasi positif Coronavirus COVID19 termasuk di Indonesia. Pemerintah sudah konsen terhadap pencegahan penyebaran COVID-19 meluas, seperti menggunakan masker jika terpaksa keluar rumah, rajin mencuci tangan dan menjaga jarak. Tujuan penelitian adalah untuk menganalisis hubungan antara pengetahuan dan sikap dengan perilaku pencegahan transmisi Covid-19, warga RT 02/05 Kelurahan Halim Perdanakusuma. Populasi penelitian adalah warga Kelurahan Halim Perdana Kusuma. Sementara sampel dalam penelitian ini berjumlah 51 orang. Hasil penelitian menunjukan bahwa variabel sikap berhubungan dengan perilaku pencegahan Transmisi Covid-19, dengan nilai Pv. 0,039 dan OR sebesar .4,190. Sementara variabel pengetahuan diperoleh hasil tidak berhubungan dengan perilaku pencegahan Transmisi Covid-19 dengan nilai P sebesar 0,40. Perlu adanya kesadaran setiap orang untuk berperilaku mencegah transmisi covid-19. Edukasi terkait bahaya penularan covid-19 harus tetap dilakukan secara masif, Secara tidak langsung memunculkan sikap positif setiap orang untuk berperilaku mencegah penularan covid-19.
\end{abstract}

Kata Kunci: Perilaku Pencegahan, Transmisi COVID -19, Pengetahun dan Sikap.

\begin{abstract}
The world is facing a pandemic outbreak caused by a new type of virus designated by WHO, namely Severe Acute Respiratory Syndrome Coronavirus - 2 (SARS-CoV-2) as Coronavirus Disease 2019 (COVID-19). The CDC (Center for Disease Control and Prevention) states, patients indicated for COVID-19 show symptoms of ARI, from mild to severe. Many people around the world have been reported and confirmed positive for Coronavirus COVID-19, including in Indonesia. The government is concerned about preventing the spread of COVID-19 from spreading, such as wearing masks when forced to leave the house, diligently washing hands and keeping a distance. The purpose of the study was to analyze the relationship between knowledge and attitudes with the behavior of preventing the transmission of Covid19, residents of Halim Perdana Kusuma Village. The population of this research is the residents of RT 02/05, Halim Perdanakusuma Village. While the sample in this study amounted to 51 people. The results showed that the attitude variable was related to the prevention behavior of Covid-19 transmission, with a $P v$ value. 0.039 and an OR of .4.190. While the knowledge variable obtained results are not related to the prevention behavior of Covid-19 transmission with a P value of 0.40. Everyone needs to be aware of how to prevent the transmission of COVID-19. Education related to the dangers of Covid-19 transmission must continue to be carried out massively, indirectly raising a positive attitude for everyone to behave to prevent the transmission of Covid-19.
\end{abstract}

Keywords: Prevention Behavior, Transmission of COVID -19, Knowledge and Attitude. 


\section{PENDAHULUAN}

Sebuah virus jenis baru telah ditetapkan oleh WHO sebagai pandemi yakni coronavirus Severe Acute Respiratory Syndrome Coronavirus - 2 (SARS-CoV -2) dikenal dengan sebutan penyakit Corona virus Disease 2019 (COVID-19) yang menyerang sistem pernapasan (PDPI. 2020). Pada tanggal 30 Januari 2020 WHO telah menetapkan sebagai Public Health Emergency of International Concern (PHEIC) (Dirjen Pencegahan dan Pengendalian Penyakit. 2020). Saat ini sudah banyak warga dunia dilaporkan dan terkonfirmasi positif Coronavirus COVID-19 termasuk di Indonesia.

Indonesia menempati urutan ke 18 kasus covid-19 dunia dan tertinggi di Asia Tenggara. Sampai bulan November 2020, konfirmasi kasus Covid-19 di Indonesia sebanyak 493.308 , sembuh 413.955 dan meninggal 15.774. DKI Jakarta menduduki peringkat pertama berdasarkan provinsi dengan jumlah kasus 125.822 dan kematian 2.509 (2.0\%) ,untuk kasus terkecil yakni provinsi Bali dengan jumlah kasus 13.012 dan kematian 406 (3.0\%) (Kemenkes, 2020).

Menanggapi hal ini, Pemerintah pun sudah mulai konsen terhadap pencegahan penyebaran COVID-19 lebih meluas, seperti menggunakan masker jika terpaksa keluar rumah, rajin mencuci tangan, mengurangi kegiatan diluar rumah. Dalam Pergub No. 33 Tahun 2020 Tentang Pelaksanaan Pembatasan Sosial Berskala Besar Dalam Penanganan Coronavirus Disease 2019 (COVID-19) menjelaskan salah satu langkah untuk mencegah penularan COVID-19 dengan melakukan Pembatasan Sosial Berskala Besar (PSBB) yakni membatasi kegiatan diluar rumah. Disamping itu juga kita sebagai masyarakat diharuskan untuk menggunakan masker saat keluar rumah, melakukan pola hidup sehat dan rajin mencuci tangan. Mencuci tangan dapat mencegah tertularnya COVID-19, karena virus ini menular melalui transmisi kontak, transmisi droplet, rute feses dan oral (PDPI. 2020).

Upaya pencegahan penularan kasus baru dalam adaptasi kebiasaan baru dengan pelaksanaan protokol kesehatan yang ketat dalam setiap aktivitas masyarakat sudah cukup masif dilakukan terutama oleh pemerintah, namun situasi di lapangan sangat berbeda dengan ekspektasi dimana masih banyak yang seolah-olah tidak peduli dengan transmisi covid-19 ini. Perilaku pencegahan transmisi ini sangat berkaitan erat dengan pengetahuan dan sikap masyarakat tentang bahaya dari virus covid-19.

Pengetahuan merupakan kenyataan dan teori yang menjadikan seseorang seseorang dapat mengetahui suatu gejala sehingga dapat memecahkan permasalah yang dihadapinya. Pegetahuan dapat diperoleh dari pengalaman dir sendir dan dari luar. Pengetahuan yang 
diperoleh dari luar berasal dari buku, teman, orang tua, guru, radio, televisi, poster, majalah dan surat kabar (Notoatmodjo, 2012). Fatimah (2014) menyatakan pengetahuan dan pengetahuan dapat mempengaruhi sikap untuk membeli suatu barang. Sikap ditentukan oleh kepercayaan individu mengenai konsekuensi dari menampilkan suatu perilaku (behavioral beliefs), ditimbang berdasarkan hasil evaluasi terhadap konsekuensinya (outcome evaluation). Sikap sikap tersebut dipercaya memiliki pengaruh langsung terhadap intensi berperilaku dan dihubungkan dengan norma subjektif dan perceived behavioral control (Han dan Kim, 2010). Perilaku merupakan suatu reaksi individu terhadap stimulus yang sangat berpengaruh pada diri seseorang baik dari dalam maupun luar pribadinya. Pengetahuan, sikap pun diyakini mempengaruhi perilaku terhadap pemeliharaan kebersihan. Perilaku terhadap pemeliharaan kebersihan memberikan kontribusi paling besar terhadap status kesehatan. Sama halnya dengan perilaku pencegahan transmisi covid 19 sangat berkaitan erat dengan bagaimana pengetahuan dan sikap dari masyarakat. Oleh karena perilaku seseorang sangat tergantung bagaimana tingkat pengetahuan dan sikap yang dimunculkan.

\section{METODE}

Penelitian ini merupakan penelitian kuantitatif analitik observasional dengan studi cross sectional. Populasi dari penelitian ini adalah warga RT 02/05 Kelurahan Halim Perdanakusuma.Variabel yang diteliti terdiri dari variabel independen (Pengetahuan dan Sikap) dan variabel dependen yaitu Perilaku Pencegahan Transmisi Covid-19. Jumlah sampel sebanyak 51 orang. Pengumpulan data menggunakan kuesioner online dan Offline, kemudian diolah dengan bantuan aplikasi perangkat lunak komputer. Teknik analisis data yang digunakan adalah analisis univariat, bivariat.

\section{HASIL DAN PEMBAHASAN}

\section{Hasil}

\section{Tabel 1}

Distribusi Perilaku Pencegahan, Pengetahuan dan Sikap Terhadap Pencegahan Transmisi Covid 19

\begin{tabular}{|c|c|c|c|}
\hline Variabel & Kategori & $\mathbf{N}$ & $\%$ \\
\hline Perilaku & Kurang & 18 & 35,3 \\
\hline Pencegahan & Baik & 33 & 64,7 \\
\hline \multirow{2}{*}{ Pengetahuan } & Kurang & 6 & 11,8 \\
\hline & Baik & 45 & 88,2 \\
\hline \multirow{2}{*}{ Sikap } & Negatif & 31 & 60,8 \\
\hline & Positif & 20 & 39,2 \\
\hline & & 51 & 100,0 \\
\hline
\end{tabular}


Pada Tabel 1 dapat dilihat bahwa Perilaku Pencegahan transmisi Covid-19 sebagian besar responden memiliki perilaku baik yaitu $64,7 \%$, sementara yang memiliki perilaku kurang baik hanya sebesar 35,3\%. Pada variabel pengetahuan, sebagian besar yaitu 88,2\% diantaranya memiliki pengetahuan yang baik tentang covid-19, sedangkan kelompok responden yang memiliki pengetahuan kurang, hanya 11,8\%. Pada variabel sikap, 68,8\% diantaranya memiliki sikap negatif, sementara yang memiliki sikap positif, hanya 39,2. Selanjutnya dalam analisis bivariat, peneliti menggunakan uji Chi-Square oleh karena semua variabel berbentuk kategorik dengan masing masing 2 kelompok kategori. Untuk lebih jelas, hasil penelitian bivariat dipaparkan dalam tabel 2 berikut.

Tabel 2.

Hubungan antara Pengetahuan dan Sikap Terhadap perilaku pencegahan Transmisi Covid-19

\begin{tabular}{|c|c|c|c|c|c|c|c|}
\hline \multirow{3}{*}{ Variabel } & \multirow{3}{*}{ Kategori } & \multicolumn{4}{|c|}{$\begin{array}{c}\text { Perilaku Pencegahan } \\
\text { Transmisi Covid-19 }\end{array}$} & \multirow{3}{*}{$\begin{array}{c}P- \\
\text { value }\end{array}$} & \multirow{3}{*}{$\underset{95 \% \mathrm{CI}}{\text { OR }}$} \\
\hline & & \multicolumn{2}{|c|}{ Kurang } & \multicolumn{2}{|c|}{ Baik } & & \\
\hline & & $\mathbf{N}$ & $\%$ & $\mathbf{n}$ & $\%$ & & \\
\hline \multirow{2}{*}{ Pengetahuan } & Kurang & 1 & 16,7 & 5 & 83,3 & \multirow[t]{2}{*}{0,405} & 0,329 \\
\hline & Baik & 17 & 37,8 & 28 & 62,2 & & $(0,035-3,063)$ \\
\hline \multirow[t]{2}{*}{ Sikap } & Negatif & 11 & 55,0 & 9 & 45,0 & \multirow{3}{*}{0,039} & \multirow{3}{*}{$\begin{array}{c}4,190 \\
(1,239-14,174)\end{array}$} \\
\hline & Positif & 7 & 22,6 & 24 & 77,4 & & \\
\hline \multicolumn{2}{|c|}{ TOTAL } & 10 & 35,3 & 33 & 64,7 & & \\
\hline
\end{tabular}

Hasil penelitian Hubungan antara Pengetahuan dan sikap terhadap perilaku pencegahan Transmisi Covid-19 dapat dilihat pada tabel 2 di atas. Adapun untuk Variabel pengetahuan, terlihat bahwa pada kelompok responden yang berpengetahuan kurang, 16,7\% diantaranya berperilaku kurang baik dalam pencegahan transmisi covid-19, sementara pada kelompok responden yang berpengetahuan baik, 37,8 \% diantaranya kurang melakukan pencegahan transmisi covid-19. Hasil uji statistic diperoleh nilai p sebesar 0,405 artinya nilai $\mathrm{P}>$ alpha 0,05 dengan demikian dapat disimpulkan bahwa tidak ada hubungan antara pengetahuan dengan perilaku pencegahan Transmisi Covid-19.

Pada variabel Sikap, responden dengan sikap negatif 55,0\% diantaranya berperilaku kurang baik dalam pencegahan transmisi covid-19, sementara responden dengan sikap positif, 22,6\% berperilaku kurang baik dalam pencegahan transmisi covid-19. Hasil uji statistic diperoleh nilai $\mathrm{p}$ sebesar 0,039 artinya $\mathrm{p}<0,05$ dengan demikian dapat disimpulkan bahwa a6da hubungan antara sikap dengan perilaku pencegahan Transmisi Covid-19. Hasil uji pula diperoleh nilai OR sebesar . 4,190 dengan CI 1,239-14,174 1,298-7,895. Artinya bahwa responden dengan sikap negatif, cenderung kurang baik dalam melakukan Pencegahan 
Transmisi Covid-19 4 kali lebih besar dibandingkan dengan responden yang memiliki sikap positif.

\section{Pembahasan}

Hasil penelitian memperlihatkan bahwa tidak ada hubungan antara pengetahuan dengan perilaku pencegahan covid-19 dimana uji statistik diperoleh nilai p sebesar 0,405 artinya nilai P> alpha 0,05. Hasil penelitian ini sejalan dengan penelitian yang dilakukan oleh Mudawaroch, 2020 yang menemukan tidak ada hubungan antara pengetahuan dengan perilaku responden menghadapi virus Corona. Berbeda dengan penelitian yang dilakukan oleh Syakurah, 2020 yang menemukan adanya hubungan antara pengetahuan dengan usaha pencegahan covid-19. Secara teori, hasil penelitian inipun berbanding terbalik dengan teori yang dijelaskan dalam Notoatmodjo 2010, bahwa tingkat pengetahuan seseorang berkaitan erat dengan perilaku.Menurut asumsi peneliti, tidak ada hubungan antara pengetahuan dengan perilaku pencegahan ini mungkin karena pada umumnya pengetahuan respoden sudah baik. Hal ini dapat dilihat pada distribusi frekuensi dimana $88 \%$ responden berpengetahuan baik. Tingkat pengetahuan yang sudah baik ini pun sangat dimungkinkan, oleh karena Situasi saat ini seseorang bisa mengakses informasi dari berbagai sumber baik dari buku, internet, perkuliahan dan lain sebagainya. Sejalan dengan pendapat (Muntaza dan Adi, 2020) dimana Tingkat pengetahuan seseorang dipengaruhi oleh informasi yang didapatkan. Sumber informasi dapat memberikan pengaruh terhadap tingkat pengetahuan dimana seseorang akan menerima landasan kognitif untuk membentuk pengetahuan.

Pada Variabel Sikap, hasil penelitian memperlihatkan adanya hubungan antara sikap dengan perilaku pencegahan Covid-19. Hasil penelitian ini sejalan dengan penelitian Syakurah, 2020 yang juga menemukan adanya hubungan antara sikap dengan perilaku pencegahan covid 19 . Sejalan juga dengan penelitian Mudawaroch, 2020 yang menemukan ada hubungan antara sikap dengan perilaku responden menghadapi virus Corona. Dalam penelitian ini, secara univariat terlihat bahwa hampir sebagian besar 60,8 responden memiliki sikap negatif. Hal ini cukup memprihatinkan, dimana seseorang bila menunjukan sikap negatif, maka perilaku yang dimunculkan pun negatif. Sikap negatif yang dimaksud disini adalah tidak tenang, kurang berhati-hati dan tidak peduli dengan pencegahan covid-19. Hasil ini berbeda dengan pendapat Meitiana (2017) yang menyatakan bahwa kesenjangan antara sikap dan perilaku tersebut menandakan bahwa sikap positif konsumen terhadap produk tidak selalu diterjemahkan ke dalam tindakan. Artinya bahwa walaupun banyak responden yang 
memiliki sikap positif terhadap virus corona, namun perilaku pencegahan yang ditujukan mereka tidak selalu sesuai dengan sikapnya.

\section{SIMPULAN DAN REKOMENDASI}

Dari 2 variabel Independen yang diteliti, adapun variabel yang berhubungan dengan perilaku Pencegahan transmisi covid-19 adalah Sikap. Sementara variabel pengetahuan, secara statistik tidak berhubungan dengan Pencegahan transmisi covid-19. Dengan demikian, maka perlu adanya kesadaran pada setiap orang untuk berperilaku mencegah transmisi covid-19. Selain itu, edukasi terkait bahaya penularan covid-19 ini harus tetap dilakukan secara masif, hal ini secara tidak langsung memunculkan sikap positif pada setiap orang untuk berperilaku mencegah penularan covid-19

\section{REFERENSI}

1. Kementerian Kesehatan RI. 2020. Pedoman Kesiapsiagaan Menghadapi Coronavirus Disease (revisi ke 2). Direktorat Jenderal Pencegahan dan Pengendalian Penyakit: Jakarta.

2. Meitiana. 2017. Perilaku Pembelian Konsumen: Sebuah Tinjauan Literatur Theory of Planned Behavior.Jurnal Ekonomi Modernisasi 13 (1) : 16-24.

3. Mudawaroch, R. E. (2020). Pengaruh Pengetahuan dan Sikap Terhadap Perilaku Mahasiswa dalam Menghadapi Virus Corona. Prosiding HUBISINTEK, 1, 257-257.

4. Muntaza, Y., A.C.Adi. 2020. Hubungan Sumber Informasi dan Pengalaman dengan Tingkat Pengetahuan tentang Penggunaan Monosodium Glutamate (MSG) pada Ibu Rumah Tangga. Amerta Nutr. 72-78. doi: 10.20473/amnt.v4i1.2020.72-78.

5. Notoatmodjo S. 2012. Promosi Kesehatan dan Perilaku Kesehatan. Jakarta: PT Rineka Cipta.

6. Perhimpunan Dokter Paru Indonesia. 2020. Pneumonia COVID-19 Diagnosis \& Tatalaksana Di Indonesia. PDPI: Jakarta.

7. Syakurah, R. A., \& Moudy, J. (2020). Pengetahuan terkait usaha pencegahan Coronavirus Disease (COVID-19) di Indonesia. HIGEIA (Journal of Public Health Research and Development), 4(3), 333-346. 
8. Tim Kerja Kementerian Dalam Negeri Untuk Gugus Tugas COVID-19. 2020. Pedoman Umum Menghadapi Pandemi COVID-19 Bagi Pemerintah Daerah: Pencegahan, Pengendalian, Diagnosis dan Manajemen. Jakarta: Kementerian Dalam Negeri

9. WHO. 2020. Pesan dan Kegiatan Utama Pencegahan dan Pengendalian Covid-19 di Sekolah. https://www.who.int/docs/default-source/searo/indonesia/covid19/pesan-dankegiatan-utama-pencegahan-dan-pengendalian-covid-19-di-sekolah---indonesian-march-2020.pdf?sfvrsn=5cdfea17_2

10. Muntaza, Y., A.C.Adi. 2020. Hubungan Sumber Informasi dan Pengalaman dengan Tingkat Pengetahuan tentang Penggunaan Monosodium Glutamate (MSG) pada Ibu Rumah Tangga. Amerta Nutr. 72-78. doi: 10.20473/amnt.v4i1.2020.72-78.

11. Han, H. and Kim, Y. 2010. An investigation of green hotel customer's decision formation: Developing an extended model of the Theory of Planned Behavior. International Journal of Hospitality Management 29: 659-668.

12. Fatimah, S., \& Fauziah, A. N. (2015). Hubungan Pengetahuan dengan Sikap Ibu Menyusui Tentang Cara Menyusui yang Benar di Klinik Utama PKU Muhammadiyah Sampangan Surakarta Tahun 2014. Jurnal Kebidanan Indonesia, 6(1). 